\title{
Hydraulic analysis of river training cross-vanes as part of post-restoration monitoring
}

\author{
T. A. Endreny ${ }^{1}$ and M. M. Soulman ${ }^{2}$ \\ ${ }^{1}$ Department of Environmental Resources Engineering, SUNY ESF, Syracuse, New York 13210, \\ 315-470-6565, USA \\ ${ }^{2}$ Department of Environmental Resources Engineering, SUNY ESF, Syracuse, New York 13210, USA
}

Received: 11 January 2011 - Published in Hydrol. Earth Syst. Sci. Discuss.: 8 March 2011

Revised: 3 June 2011 - Accepted: 19 June 2011 - Published: 8 July 2011

\begin{abstract}
River restoration design methods are incrementally improved by studying and learning from monitoring data in previous projects. In this paper we report postrestoration monitoring data and simulation analysis for a Natural Channel Design (NCD) restoration project along $1600 \mathrm{~m}$ of the Batavia Kill ( $14 \mathrm{~km}^{2}$ watershed) in the Catskill Mountains, NY. The restoration project was completed in 2002 with goals to reduce bank erosion and determine the efficacy of NCD approaches for restoring headwater streams in the Catskill Mountains, NY. The NCD approach used a reference-reach to determine channel form, empirical relations between the project site and reference site bankfull dimensions to size channel geometry, and hydraulic and sediment computations based on a bankfull (1.3 yr return interval) discharge to test channel capacity and sediment stability. The NCD project included 12 cross-vanes and $48 \mathrm{j}$-hook vanes as river training structures along 19 meander bends to protect against bank erosion and maintain scour pools for fish habitat. Monitoring data collected from 2002 to 2004 were used to identify aggradation of pools in meander bends and below some structures. Aggradation in pools was attributed to the meandering riffle-pool channel trending toward steppool morphology and cross-vane arms not concentrating flow in the center of the channel. The aggradation subsequently caused flow splitting and 4 partial point bar avulsions during a spring 2005 flood with a 25 -yr return interval. Processing the pre-flood monitoring data with hydraulic analysis software provided clues the reach was unstable and preventative maintenance was needed. River restoration and monitoring teams should be trained in robust hydraulic analytical methods that help them extend project restoration goals and structure stability.
\end{abstract}

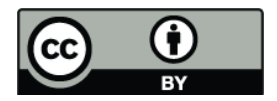

Correspondence to: T. A. Endreny (te@esf.edu)

\section{Introduction}

River restoration has evolved from a niche field practiced by specialists to an expansive enterprise undertaken by government agencies, private industry, and the academic community. Since 1990, the number of restoration projects in the United States has increased exponentially, totaling 37099 by 2005 , and the annual cumulative cost for these projects is approximately $\$ 1$ billion per year (Bernhardt et al., 2005). The many restoration projects represent a few common goals, including enhancing water quality, replanting riparian vegetation, improving aquatic habitat, and reducing excessive erosion and deposition (Bernhardt and Palmer, 2007; Bernhardt et al., 2007). Economic costs of river bank erosion, however, have been estimated at $\$ 16$ billion per year (Radspinner et al., 2010), which suggests river restoration is a wise investment if the projects meet their goals. This paper reports on the localized failure of one restoration project and how post-restoration monitoring data and complementary hydraulic simulation and analysis might have extended project stability.

Post-restoration monitoring is generally considered uncommon and inadequate - too few rivers are monitored, and the data, if collected, generally do not relate to project goals (Palmer et al., 2007; Kondolf et al., 2007). The National River Restoration Science Synthesis project determined when post-restoration monitoring data were collected they were rarely used as an assessment to inform the project team or larger community of restoration professionals (Bernhardt et al., 2005). Restoration post-monitoring guidelines are available, and those advocated by Kondolf (1995) include: (a) noting the restoration project objectives, (b) collecting pre-restoration data as a baseline, (c) conducting multi-year post-restoration monitoring, (d) communicating failures as valuable information to inform future design. Learning from project failure is not unique to river

Published by Copernicus Publications on behalf of the European Geosciences Union. 
restoration; most engineering designs are improved through failure analysis (Petrosky, 2008).

The river restoration project discussed in this paper was designed to reduce bank erosion and the subsequent turbidity entering a New York City (NYC) drinking water supply reservoir. The project goals also included learning how restoration worked in the mountainous region (GCSWCD, 2006). The project was part of a multi-million dollar watershed restoration program intended to deliver clean drinking water and avoid the estimated \$6 billion to construct a NYC water treatment facility (Chichilnisky and Heal, 1998). Restoration projects might follow any of numerous guidelines, including those provided by the Federal Interagency Stream Restoration Working Group (FISRWG, 1998), the American Society of Civil Engineers River Restoration Working Group (Shields et al., 2003), and prescribed under the European Union Habitats Directive and Water Framework Directive (Clarke et al., 2003). According to Malakoff (2004), the Natural Channel Design (NCD) approach (Rosgen, 1994, 2006), is one of the most influential approaches in river restoration, but possibly the most controversial (Lave, 2009). Simon et al. (2007) contend the NCD approach is overly empirical and neglects physically based, mechanistic approaches to quantify driving and resisting forces that predict success in channel stability projects. Rosgen (2008) asserts the NCD results in successful projects because it uses mechanistic equations together with empirical relations to process site data. Our paper demonstrates how monitoring data from an NCD project can reveal the initial patterns of bedform instability and support hydraulic simulations and analysis to examine causes of degradation, aggradation, and bank vulnerability.

\section{Methods}

\subsection{Basis for restoration}

The NYC based restoration project used the NCD approach (Rosgen, 2006, 2008; Keystone Stream Team, 2003; Hey, 2006), defined as including: (1) an analog approach to determine dimensionless river morphology (e.g., width-to-depth ratio, slope, sinuosity, wavelength relative to channel width, radius of curvature relative to channel width, etc.) via surveys of a stable condition reference reach in an equivalent watershed and climatic regime; (2) an empirical approach to determine river geometry magnitudes at the project site based on a target bankfull depth, width, or discharge (e.g., determine width based on width-to-depth ratio and estimates of bankfull depth); and (3) an analytical approach with hydraulic computations at bankfull discharge to test channel capacity and sediment stability.

The erosion control NCD restoration project was built in 2001 and 2002 along a $1600 \mathrm{~m}$ section of the Batavia Kill called the Big Hollow restoration project reach (see

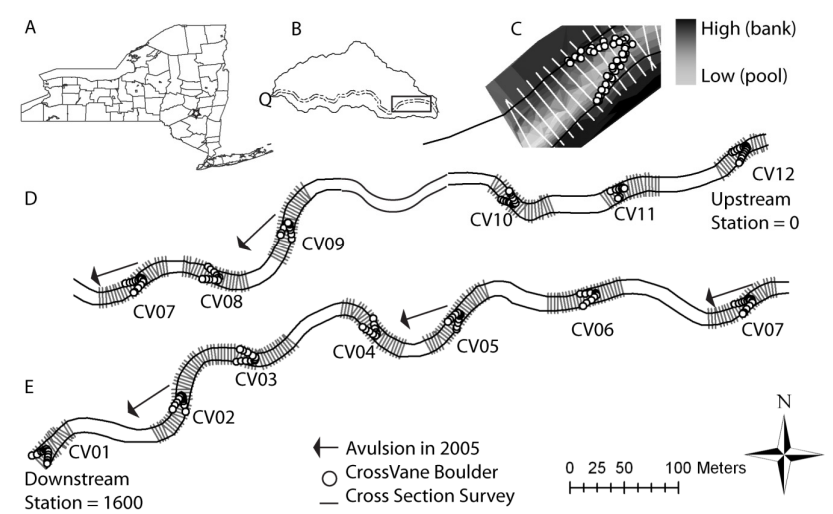

Fig. 1. (A) Location in New York of (B) Batavia Kill watershed. (C) Diagram of a cross-vane and its scour pool. (D) Upstream reach of restoration project with 6 cross-vanes and (E) downstream reach of project, where arrows show the avulsion sites.

Fig. 1). A pre-restoration survey noted the absence of riparian vegetation and estimated $55 \%$ of the Big Hollow reach was actively eroding at rates of $3.7 \mathrm{~m}^{2}$ per linear meter of stream, with mass wasting along a $330 \mathrm{~m}$ of reach with a $15 \mathrm{~m}$ high terrace of dense glacial till (GCSWCD, 2006). The project team observed pre-restoration avulsions and migration in laterally unstable meanders, and also noted incision and debris dams in vertically unstable sections that had been straightened to pass under bridges (GCSWCD, 2006). Prior to the restoration project the restoration team measured 8750 tonne $\mathrm{yr}^{-1}$ of sediment was leaving the Big Hollow reach due to bank erosion, and they estimated the rate might triple without restoration and adversely impact NYC drinking water supplies (GCSWCD, 2006). During the first three years after the restoration project erosion from the site was measured at 2520 tonne $\mathrm{yr}^{-1}$ but then increased to 8440 tonne $\mathrm{yr}^{-1}$ in 2005 when a large storm caused several point bar avulsions (GCSWCD, 2006). The Big Hollow restoration project experienced areas of failure during an April 2005 rain-on-snow flood event that caused four avulsions in the reach (see arrows in Fig. 1d and e). Based on a watershed area scaling of annual maximum discharge data from the upstream US Geological Survey (USGS) gage (\#01349840, Maplecrest, NY) the flood discharge was estimated at $57 \mathrm{~m}^{3} \mathrm{~s}^{-1}$ with a return interval of 25-yr. By contrast, the NCD project was designed for a bankfull discharge of $14.6 \mathrm{~m}^{3} \mathrm{~s}^{-1}$ with a return interval of 1.3-yr, which compares well with USGS regional curve based bankfull discharge estimates for the watershed area (Mulvihill et al., 2009).

\subsection{Project site and monitoring}

The Big Hollow restoration project along the Batavia Kill in the Catskill Mountains, NY was completed in two phases, with $1100 \mathrm{~m}$ of the downstream project constructed in 2001 
and $500 \mathrm{~m}$ of the upstream project constructed in 2002. In addition to the morphological monitoring reported in this project, fish communities and habitat were monitored for this site (Baldigo et al., 2010). The project is on a thirdorder river, with an upstream drainage area of $14 \mathrm{~km}^{2}$ and downstream drainage area of $19 \mathrm{~km}^{2}$. Riparian vegetation was replanted in small shrubs and trees following restoration, and forest cover was extensive further into the floodplain. The watershed is predominantly forested but also contained a small low-density residential community. The valley slope was $2 \%$ and the restoration channel had a slope of $1.4 \%$ with a sinuosity of 1.2.

The Big Hollow restoration project included 19 meander bends and used 12 cross-vane structures and 48 j-hooks (Rosgen, 2001; Keystone Stream Team, 2003) as river training structures around the meanders and within riffles. The structures redirect bank scour forces and keep the bankfull erosion forces in the channel center. Cross-vane structures were constructed from boulders that connected in a trapezoidal shape in planview, the base and each arm designed to occupy $33 \%$ of the channel width. The base of the trapezoid, called the sill, has a crest height at or just above the bed elevation, and the arms extend from the sill in a downstream direction, rising in elevation to connect with the banks at bankfull height. J-hook structures are equivalent to half a cross-vane, attached to the scour bank. The structures have relatively simple design specifications intended to steer the flow away from the bank, establish grade control, maintain a stable width-to-depth ratio, maintain shear stress to move the largest substrate size, decrease near-bank stress, maintain channel capacity, ensure stability during floods, and maintain fish passage (Rosgen, 2001).

In 2002, 2003, and 2004 cross-section surveys were completed at 35 monumented cross-sections; 24 of these crosssections were pools. In 2004 surveys were completed at each of the 12 cross-vanes, extending 1 channel width upstream and downstream of the structure. The surveys were conducted with a TopCon GTS-605 Total Station, a Husky MP2500 data logger and a prism rod. For each survey, the total station was set up over a monumented point, with known coordinates. The survey of each cross-vane site included the river banks, floodplain, structure, and other relevant features, and consisted of 200-350 points. The points were taken by walking lines parallel to the thalweg of the river, along the banks (e.g., top of bank, bottom of bank), through the channel (e.g., thalweg center), and on the water surface (e.g., water surface left). The cross-vanes were surveyed in lines along their perimeter (e.g., outer edge, inside bottom edge). A triangulated irregular network surface was generated for each cross-vane survey and cross-sections and pool characteristics were extracted.

Cross-sectional survey data were used to analyze trends in pool depth and width-to-depth ratio. Cross-vane surveys were used to examine whether there were significant variations in the geometry between vanes. Cross-vane design

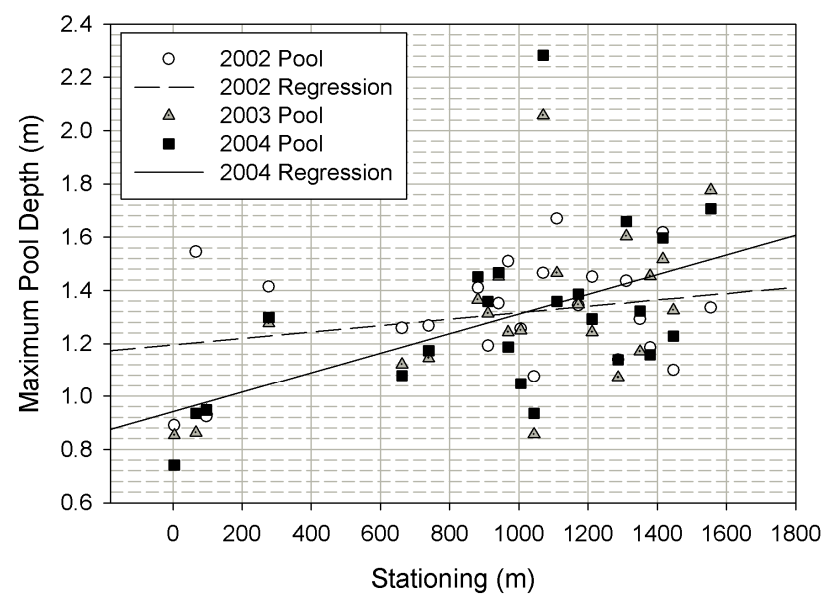

Fig. 2. Maximum pool depth for 24 monitored pool cross-sections for 2002, 2003, and 2004 with trend lines for 2002 and 2004 (upstream stationing is $0 \mathrm{~m}$ ).

specifications direct the vane arm leave each bank at the bankfull height and continue upstream toward a weir sill in the middle-third of the channel. The vane arms should have a $20-30^{\circ}$ horizontal angle off the bank, and a $3-7 \%$ vertical slope to the weir sill (Keystone Stream Team, 2003; NCSRI and NCSG, 2001). Particular attention was paid to the project reach where avulsions occurred during the April 2005 flood. The avulsions were located near cross-vanes 2, 5, 7, and 9 , where cross-vane number increases in the upstream direction.

Monitoring data were analyzed with publically available simulation tools. The HEC-RAS 1D simulation tool (USACE, 2008) was used to examine channel conveyance along the restoration reach. HEC-RAS uses a finite difference method to solve the conservation of mass and energy equations, and in cases where there is a hydraulic jump, it uses conservation of mass and momentum equations. The River2D (Steffler and Blackburn, 2002) depth-averaged hydrodynamic simulation tool was used to examine velocity distribution within the channel and determine if the vanes were reducing high velocity vectors. River2D uses a finite element method to solve a conservation of mass equation and 2 horizontal components of the conservation of momentum equations. Terrain inputs for both models were derived from the topographic surveys, Manning roughness was set to 0.035 based on gravel to cobble substrate, and flow was simulated at bankfull discharge of $14.6 \mathrm{~m}^{3} \mathrm{~s}^{-1}$.

\section{Results}

Between 2002 and 2004, pool depth generally increased in the downstream direction in the Big Hollow restoration project (Fig. 2). In 2002 the upstream $800 \mathrm{~m}$ of the project had average pool depths of $1.2 \mathrm{~m}$, only $0.1 \mathrm{~m}$ shallower than 


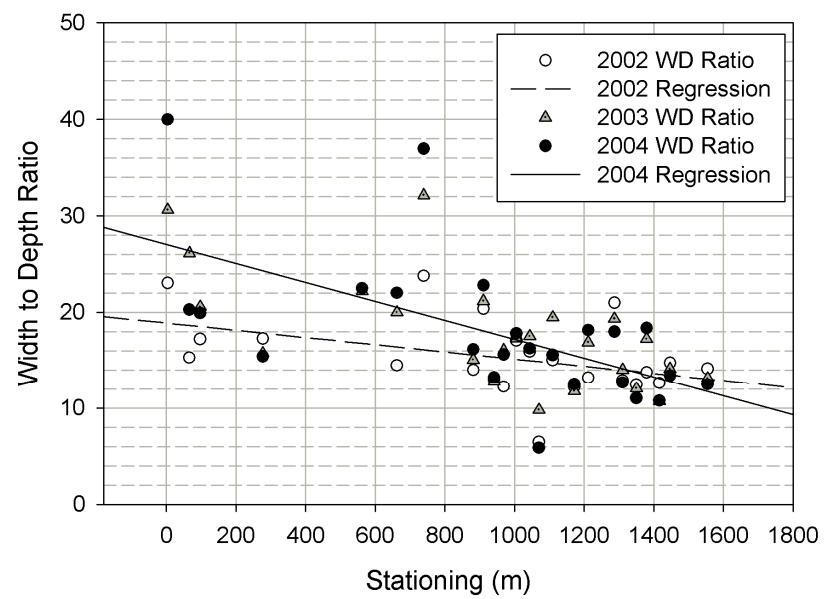

Fig. 3. Width-to-depth ratios for 24 monitored pool cross-sections for 2002, 2003, and 2004 with trend lines for 2002 and 2004 (upstream stationing is $0 \mathrm{~m}$ ).

the downstream $800 \mathrm{~m}$ of project average pool depths. In 2002 the upstream section had the only 3 pools shallower than $1 \mathrm{~m}$. In 2004 the upstream pools had aggraded to an average depth of $1 \mathrm{~m}$, while the downstream pools had increased to an average depth of $1.4 \mathrm{~m}$, with one pool scouring from 1.5 to $2.3 \mathrm{~m}$. By 20046 of the 7 upstream pools had partially aggraded. In the downstream section, the trend for pools was mixed, with 9 of 17 pools aggrading, including those downstream of the later avulsions. A survey of the cross-sections after the 2005 flood documented aggradation in the pools downstream of the avulsions (Buck-Engineering PC, 2006).

Width-to-depth ratio decreased in the downstream direction (Fig. 3), with several monitored banks eroding between 1 and $9 \mathrm{~m}$ and aggradation on the opposite bank not completing the lateral migration (Buck-Engineering PC, 2006). Reach average width-to-depth ratios were 15 in 2002 and 18 in 2004 . In the $800 \mathrm{~m}$ upstream section, the average ratio increased from 18 in 2002 to 24 in 2004, while the $800 \mathrm{~m}$ downstream section had an average ratio of 14 across the $3 \mathrm{yr}$. The upstream to downstream trend in decreasing ratios steepened between 2002 and 2004. Despite variation in widthto-depth ratios, all of the measured values were within the normal range reported for stable cross-vane restored rivers (Radspinner et al., 2010). Detailed analysis of cross-section morphology from 2002 to 2004 revealed the upstream pools within meander bends were eroding at one bank and filling with sediment elsewhere and became morphologically similar to plane bed or riffle sections (Buck-Engineering PC, 2006). HEC-RAS simulation of bankfull discharge for the 2004 morphology was used to examine how aggradation impacted cross-sectional area. Analysis of model output included 267 cross-sections, with 100 pool cross-sections. The analysis showed the 25th quartile pool cross-sectional area

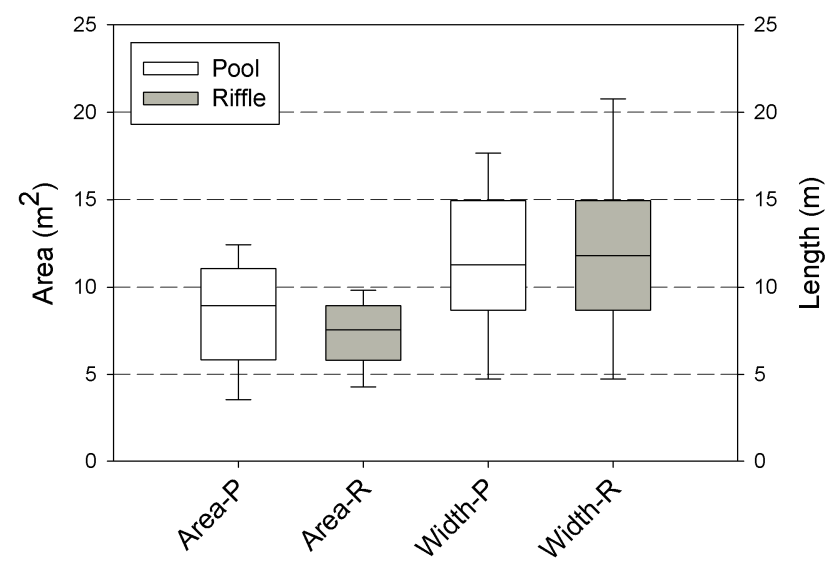

Fig. 4. Box and whiskers plot of bankfull flow cross-sectional area and width for pools and riffles based on HEC-RAS simulation with 2004 survey data.

was smaller than the 25th quartile riffle area, and the pool and riffle widths were nearly equal (Fig. 4).

The 2004 survey of the 12 cross-vanes revealed the vane geometry departed from design standards (Table 1). The vane's vertical arm slopes ranged from $2-10 \%$, with 4 arm slopes outside the design range of 3-7\%. The vane's horizontal arm angles off the bank ranged from $10-23^{\circ}$, with 10 arms below of the design range of $20-30^{\circ}$. Based on NCD guidance (Rosgen, 2001) vanes that do not reach a $20^{\circ}$ angle do not concentrate flow as narrowly in the middle third of the river, and would cause wider, shallower and less powerful flows and likely lead to aggradation. Because of the smaller horizontal angles, many of the vane arms did not occupy one-third of the bankfull width of the channel. Despite design departures that should cause aggradation below vanes, 5 cross-vane pools instead experienced significant scour and degradation. The explanation for this degradation at an over-widened cross-vane may be local hydraulic slopes over the vane sill that increased shear forces and caused scour (Thompson, 2002).

An analysis of river hydraulic slopes passing over vanes and shear forces along the bed was conducted using HECRAS simulations with the 2004 bed geometry and bankfull discharge. The simulated water surface profile had rapidly varied flow at all cross-vanes, with hydraulic jumps predicted in many of the pools (Fig. 5). The hydraulic jumps below vanes are associated with deeper pools and this situation contrasts with the absence of hydraulic jumps in the meander bends where there was notable aggradation of the pools. Pools below vanes varied in depth, and the deeper pools had steep water surface and energy grade line slopes ranging between $10-20 \%$. A cross-section shear force of $60 \mathrm{Nm}^{-2}$ was the median model value predicted by HEC-RAS for bankfull discharge, but in the deeper pools the shear was above $140 \mathrm{Nm}^{-2}$. Based on Shields critical shear stress analysis 
Table 1. Cross-vane arm angle, slope, and ratio of arm and sill length to bankfull width.

\begin{tabular}{|c|c|c|c|c|c|c|c|}
\hline \multirow[t]{2}{*}{ Cross Vane \# } & \multicolumn{2}{|c|}{ Arm Angle $\left({ }^{\circ}\right)^{1}$} & \multicolumn{2}{|c|}{ Arm Slope $(\%)^{2}$} & \multicolumn{3}{|c|}{ Ratio $^{3}$} \\
\hline & Left & Right & Left & Right & Left & Sill & Right \\
\hline 1 & 14 & 13 & 5.8 & 5.2 & 0.19 & 0.45 & 0.22 \\
\hline 2 & 14 & 17 & 10.2 & 5.9 & 0.44 & 0.42 & 0.57 \\
\hline 3 & 10 & 13 & 6.4 & 6.4 & 0.26 & 0.41 & 0.33 \\
\hline 4 & 10 & 23 & 6.9 & 5.2 & 0.26 & 0.35 & 0.56 \\
\hline 5 & 18 & 13 & 9.5 & 7.1 & 0.37 & 0.29 & 0.24 \\
\hline 6 & 17 & 11 & 6.8 & 4.8 & 0.29 & 0.16 & 0.18 \\
\hline 7 & 12 & 18 & 5.1 & 4.6 & 0.23 & 0.32 & 0.33 \\
\hline 8 & 16 & 15 & 5.0 & 4.5 & 0.32 & 0.31 & 0.28 \\
\hline 9 & 19 & 21 & 4.8 & 2.1 & 0.26 & 0.17 & 0.29 \\
\hline 10 & 18 & 12 & 4.3 & 6.1 & 0.58 & 0.49 & 0.41 \\
\hline 11 & $n-a$ & 11 & $n-a$ & 3.8 & $\mathrm{n}-\mathrm{a}$ & 0.27 & 0.19 \\
\hline 12 & 16 & 11 & 3.3 & 4.0 & 0.56 & 0.26 & 0.36 \\
\hline
\end{tabular}

${ }^{1}$ Angle $=$ Arm angle (degrees) in horizontal plane, from bank to sill.

2 Slope $=$ Arm slope $($ percent $)$ in vertical plane, from bank to sill.

${ }^{3}$ Ratio $=$ Ratio of entity width over bankfull width.

the median shear force can move the Big Hollow 50\% diameter (D50) particle of $63 \mathrm{~mm}$ and the deeper pool shear force can move the D84 particle of $200 \mathrm{~mm}$. The flatter and shallower pool and riffle sections would not have the competence to move these D84 particles. River velocity vectors were analyzed with the River2D simulations to examine whether the river training structures were steering velocity off the scour banks. River2D simulations of the 2004 bed form near crossvanes 7 and 9 identified velocity vectors striking against the banks where the avulsions occurred (see Fig. 5, inset). The absence of river training devices allowed high velocity vectors to access the bank and initiate the avulsions.

\section{Discussion}

River restoration projects have been completed by a large number of practitioners with variable design methods, site morphologies, and boundary conditions. The NCD design process advocates for standard engineering hydraulic computations to check for channel capacity and sediment competence given the site conditions. Radspinner et al. (2010) surveyed NCD practitioners and learned $80 \%$ of 64 respondents considered cross-vane design guidelines adequate. Yet subsequent interviews revealed most wanted better quantitative predictive methods for cross-vane design, possibly revealing their aspiration for more robust designs. The hydraulic and sediment modeling tools provided for design use the bankfull discharge, and these same tools should be useful for post-restoration analysis and could continue to inform project management. Two possible models are HEC-RAS and River2D, used in our analysis of Batavia Kill crossvanes. Project teams can find guidance on how to parame-

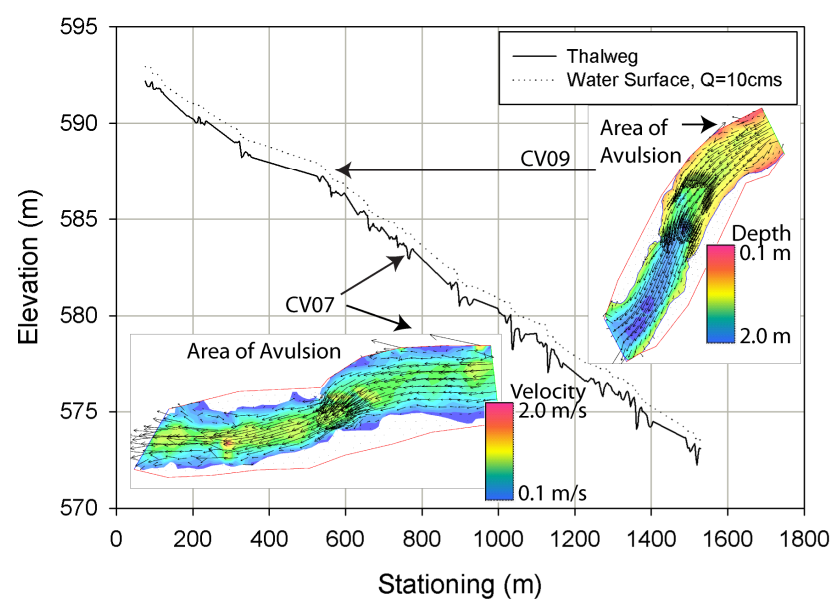

Fig. 5. HEC-RAS predicted water surface slopes along the project reach with inset of River2D predicted flow velocity and depth with velocity vectors at cross-vane 7 and 9 .

terize HEC-RAS using a sensitivity study that ran 1 million simulations to determine adequate and optimal NCD field data accuracy, cross-section survey density, and parameter estimation techniques (Kuta et al., 2010).

Post-restoration monitoring can identify local problems as well as contribute to the necessary and larger effort to improve restoration design. For the Batavia Kill in the Catskill Mountains of NY the project team initiated monitoring immediately after project construction and continued through the period of aggradation and degradation at cross-vanes and avulsions at the nearby point bars. Monitoring data revealed the pools in the meander bends and some pools below crossvanes were experiencing aggradation, while pools below 
similarly designed cross-vanes were experiencing degradation. Even though nearly all the cross-vanes had improperly sized arm angles and may not have maximized flow concentration at the channel thalweg, this did not lead to systematic aggradation of pools. HEC-RAS analysis suggested variation in pool depths below vanes was associated with variation in water surface slopes and erosive energy. A detailed analysis of aggradation and bank widening data in meander bend pools showed the reach morphology was approaching a plane bed or riffle bed form. Conversely, analysis of riffle sections at cross-vanes suggested the step-pool transitions were a laterally more stable bed form for this mountain reach. Ultimately, monitoring data analysis did not initiate preventative measures to avoid the point bar avulsions generated during the April 2005 flood. This 25-yr return interval flood exceeded the 1.3-yr design flood and could be considered beyond the project scope. Given the site history of avulsions, lateral migration, and the 2002 to 2004 aggradation, an adaptive management plan to prevent or respond to avulsions and aggradation is justified. The local migration and avulsion failures along the restoration project may be due to a combination of pool-riffle meander design in a mountain location where a step-pool bedform is more stable and of not adequately establishing bank protection with vegetation and strategically-placed river training structures.

Reporting on river restoration project performance is one method to advance our collective understanding of what is working and how to design better restoration projects. This article illustrates the utility of post-restoration monitoring data, analyzed to reveal trends in bed morphology as well as to parameterize river hydraulic simulations and analysis. By engaging in a cycle of data collection, processing, and analysis project teams can motivate preventative maintenance operations and extend project lifetimes. For Batavia Kill preventative maintenance might have involved removing bars of aggraded sediment, replacing low-gradient meander bends with step-pool sequences, and reworking river training structures to deflect scour forces from banks where avulsions occurred. Based on this experience, we update the post-restoration monitoring list of Kondolf (1995): (a) state river restoration objectives, (b) collect baseline prerestoration data related to objectives, (c) collect and analyze trends in post-restoration monitoring data related to objectives, (d) simulate and analyze river processes and consider if processes threaten the project objectives, and (e) share project lessons to inform future designs. Given that rivers ARE dynamic systems and society is seeking to design stable river reaches, we need more river scientists and engineers engaging in post-restoration monitoring, analysis, and lesson sharing.

The Big Hollow restoration project history contrasts and compares with other NCD post-restoration reports. Areas of contrast include its location; there are few reports on river restoration project history in the Catskill Mountains. Nagle (2007) levels a critique on articles too often returning to the same few post-restoration locations (e.g., upstream of a bridge constriction on bed-load rich Uvas Creek, CA), repeating the same lessons and not building the knowledge base. Another area of contrast is the reporting on avulsions in a project with 12 cross-vanes. Niezgoda and Johnson (2006) report on two NCD projects, each with 3 cross-vanes, that did not experience channel failure. In an effort to catalog national post-monitoring data on cross-vane performance, Radspinner et al. (2010) use this same study to conclude crossvanes can stabilize the channel when used in the right number and spacing. In the Radspinner et al. (2010) survey of causes for cross-vane failure they list faulty installation and improper boulder size and shape, which our study might contribute to variation in hydraulic gradients over vanes and relate to variation in cross-vane arm angle and slope. The reported modes of failure for cross-vanes were summarized by Radspinner et al. (2010) and included aggradation, similar to our Batavia Kill site, but also included lateral circumvention, displacement of boulders, and local scour.

Smith and Prestegaard (2005) conducted a post-restoration morphological and hydraulic analysis on a NCD project on Deep Run, MD that contrasts with our study. Their study site included several $\mathrm{v}$-shaped grade controls at the cross-over riffle, and the structures could be similar if not identical to cross-vanes. Differences in the studies include their expansion of discharge analysis to range from $25 \%$ of bankfull to the out-of-bank 10-yr return interval flow (Smith and Prestegaard, 2005). To assess channel stability they used an innovative method to compute local shear stress values at multiple cross-sections rather than a single shear computed by crosssection averaged hydraulic radius and friction slopes (Smith and Prestegaard, 2005). However, they reported difficulty in determining systematic channel adjustments given the complexity of hydraulic processes and the complicating presence of the rigid grade control structures (Smith and Prestegaard, 2005). Their study recommended development of refined equations relating hydraulic resistance to channel stability (Smith and Prestegaard, 2005); we support this goal and until it is reached we recommend project teams use the publically available models, such as HEC-RAS and River2D, to analyze and manage these systems.

\section{Summary}

River channels are intended to convey water and sediment and therefore we should expect river restoration projects will weather under hydraulic and scour forces. In recognition of this dynamic system restoration goals might include a lifetime of regular maintenance and periodic rerestoration. However, to minimize maintenance and restoration upkeep, post-restoration monitoring of river restoration projects should assess how projects respond over time and then identify best or worst practices. This study examined a NCD river restoration project intended to control erosion 
from entering the NYC drinking water supply. Aggradation was prominent in flatter sloped meander bends and this may have caused subsequent point bar avulsions during the 2005 flood event, which led to more serious water quality impacts. While post-restoration monitoring on this project noted aggradation problems, activity stopped there; hydraulic and sediment analyses were not conducted to determine the cause or remedy the aggradation. We advocate for post-restoration monitoring combined with complementary hydraulic and sediment analysis, particularly at river training structures, to optimize maintenance and extend river restoration goals.

\section{Evaluation criteria}

The manuscript was prepared to present substantial new data on a major river restoration project.

Acknowledgements. Financial graduate student support was provided by a grant from the Edna Bailey Sussman Foundation. Logistical data collection support was provided by the NYC DEP and Greene County Soil and Water Conservation District. Publication cost support was provided by the University at Buffalo ERIE program. Helpful editorial suggestions were provided by M. Gooseff and D. Shields.

Edited by: M. Gooseff

\section{References}

Baldigo, B. P., Ernst, A. G., Warren, D. R., and Millar, S. J.: Variable Responses of Fish Assemblages, Habitat, and Stability to Natural-Channel-Design Restoration in Catskill Mountain Streams, T. Am. Fis. Soc., 139, 449-467, 2010.

Bernhardt, E. S. and Palmer, M. A.: Restoring streams in an urbanizing world, Freshwater Biol., 52, 738-751, doi:10.1111/j.13652427.2006.01718.x, 2007.

Bernhardt, E. S., Sudduth, E. B., Palmer, M. A., Allan, J. D., Meyer, J. L., Alexander, G., Follastad-Shah, J., Hassett, B., Jenkinson, R., Lave, R., Rumps, J., and Pagano, L.: Restoring rivers one reach at a time: Results from a survey of US river restoration practitioners, Restor. Ecol., 15, 482-493, 2007.

Bernhardt, P. M. A., Alexander, A. J. D., Barnas, G. K., Brooks, S., Carr, J., Clayton, S., Dahm, C., Follstad-Shah, J., Galat, D., Gloss, S., Goodwin, P., Hart, D., Hassett, B., Jenkinson, R., Katz, S., Kondolf, G. M., and Lake, P. S.: Synthesizing River Restoration Efforts, Science, 308, 636-637, 2005.

Buck-Engineering PC: Batavia Kill watershed stream design and monitoring evaluation, Greene County, New York, Greene County Soil and Water Conservation District \& New York City Department of Environmental Protection, Cary, NC, 2006.

Chichilnisky, G. and Heal, G.: Economic Returns from the Biosphere, Nature, 391, 629-630, 1998.

Clarke, S. J., Bruce-Burgess, L., and Wharton, G.: Linking form and function: towards an eco-hydromorphic approach to sustainable river restoration, Aquat. Conserv., 13, 439-450, doi:10.1002/aqc.591, 2003.
FISRWG: Stream Corridor Restoration - Principles, Processes, and Practices, Federal Interagency Stream Restoration Working Group (FISRWG), Washington, DCNTIS: PB98-158348INQ, 1998.

GCSWCD: Big Hollow Restoration Project - Batavia Kill Implementation and Monitoring Report, Green County Soil and Water Conservation District, Cairo, NY, 2006.

Hey, R. D.: Fluvial Geomorphological Methodology for Natural Stable Channel Design, J. Am. Water Resour. As., 42, 357-374, 2006.

Keystone Stream Team: Guidelines for Natural Stream Channel Design for Pennsylvania Waterways, Alliance for Chesapeake Bay \& Pennsylvania Department of Environmental Protection, Williamsport, PA, 90, 2003.

Kondolf, G. M.: Five Elements for Effective Evaluation of Stream Restoration, Restor. Ecol., 3, 133-136, 1995.

Kondolf, G. M., Anderson, S., Lave, R., Pagano, L., Merenlender, A., and Bernhardt, E. S.: Two decades of river restoration in California: What can we learn?, Restor. Ecol., 15, 516-523, 2007.

Kuta, R. W., Annable, W. K., and Tolson, B. A.: Sensitivity of Field Data Estimates in One-Dimensional Hydraulic Modeling of Channels, J. Hydraul. Eng.-ASCE, 136, 379-384, doi:10.1061/(asce)hy.1943-7900.0000187, 2010.

Lave, R.: The Controversy Over Natural Channel Design: Substantive Explanations and Potential Avenues for Resolution, J. Am. Water Resour. As., 45, 1519-1532, doi:10.1111/j.17521688.2009.00385.x, 2009.

Malakoff, D.: Profile: The River Doctor, Science, 305, 937-939, 2004.

Mulvihill, C. I., Baldigo, B. P., Miller, S. J., DeKoskie, D., and DuBois, J.: Bankfull Discharge and Channel Characteristics of Streams in New York State, U.S. Geological Survey, Reston, VA, Scientific Investigations Report 2009-5144, 2009.

Nagle, G.: Evaluating Natural Channel Design Stream Projects, Hydrol. Process., 21, 2539-2545, 2007.

NCSRI, and NCSG: Stream Restoration: A Natural Channel Design Handbook, North Carolina Stream Restoration Institute and North Carolina Sea Grant, Raleigh, NC, 128, 2001.

Niezgoda, S. L. and Johnson, P. A.: Modeling the long term impacts of using rigid structures in stream channel restoration, J. Am. Water Resour. As., 42, 1597-1613, 2006.

Palmer, M., Allan, J. D., Meyer, J., and Bernhardt, E. S.: River restoration in the twenty-first century: Data and experiential future efforts, Restor. Ecol., 15, 472-481, 2007.

Petrosky, H.: Success through Failure: The Paradox of Design, Princeton University Press, Princeton, NJ, 256 pp., 2008.

Radspinner, R. R., Diplas, P., Lightbody, A. F., and Sotiropoulos, F.: River Training and Ecological Enhancement Potential Using In-Stream Structures, J. Hydraul. Eng.-ASCE, 136, 967-980, doi:10.1061/(asce)hy.1943-7900.0000260, 2010.

Rosgen, D. L.: A Classification of Natural Rivers, Catena, 22, 169_ 199, 1994.

Rosgen, D. L.: The Cross-Vane, W-Weir and J-Hook Vane Structure... Their Description, Design and Application for Stream Stabilization and River Restoration, Proceedings of the 2001 Wetlands Engineering \& River Restoration Conference, August 2731, 2001, Reno, Nevada, 2001,

Rosgen, D. L.: River Restoration using a Geomorphic Approach for Natural Channel Design, Proceedings of the Eighth Federal In- 
teragency Sedimentation Conference, August 2-6, 2006, Reno, Nevada, 2006,

Rosgen, D. L.: Discussion, "Critical Evaluation of How the Rosgen Classification and Associated 'Natural Channel Design' Methods Fail to Integrate and Quantify Fluvial Processes and Channel Responses", edited by: Simon, A., Doyle, M., Kondolf, M., Shields Jr., F. D., Rhoads, B., McPhillips, M., JAWRA, J. Am. Water Resour. As., 44, 782-792, 2008.

Shields, F. D. J., Copeland, R. R., Klingeman, P. C., Doyle, M. W., and Simon, A.: Design for Stream Restoration: ASCE River Restoration Working Group, J. Hydraul. Eng.-ASCE, 129, 575584, 2003.

Simon, A., Doyle, M., Kondolf, M., Shields Jr., F. D., Rhoads, B., and McPhillips, M.: Critical Evaluation of How the Rosgen Classification and Associated "Natural Channel Design" Methods Fail to Integrate and Quantify Fluvial Processes and Channel Response, J. Am. Water Resour. As., 43, 1117-1131, 2007.
Smith, S. M. and Prestegaard, K.: Hydraulic Performance of a Morphology-Based Stream Channel Design, Water Resour. Res., 41, W11413, 17 pp., doi:10.1029/2004WR003926, 2005.

Steffler, P. and Blackburn, J.: River2D: Two-Dimensional Averaged Model of River Hydrodynamics and Fish Habitat, University of Alberta, Calgary, 2002.

Thompson, D. M.: Geometric Adjustment of Pools to Changes in Slope and Discharge: A Flume Experiment, Geomorphology, 46, 257-265, 2002.

USACE: HEC-RAS River Analysis System Hydraulic Reference Manual Version 4.0, U.S. Army Corps of Engineers Hydrologic Engineering Center, Davis, CACPD-68, 2008. 